\title{
Okullardaki Örgütsel Belirsizlik Düzeyini Belirleme Ölçeği'nin Geliştirilme Çalışması $^{{ }^{*}}$
}

\author{
Esef Hakan TOYTOK
}

Doç. Dr., Kahramanmaraş Sütçü İmam Üniversitesi, Eğitim Fakültesi, Eğitim Bilimleri Bölümü hakantoytok@hotmail.com

Orcid ID: https://orcid.org/0000-0003-3638-1901

\author{
Merve YAVUZ \\ Bilim Uzmanı, Çukurova Üniversitesi \\ Eğitim Bilimleri Enstitüsü, Okul Öncesi Ana Bilim Dalı Doktora Öğrencisi \\ yavuzmerve93@gmail.com \\ Orcid ID: https://orcid.org/0000-0003-4163-087X
}

\section{Öz}

$\mathrm{Bu}$ araştırmanın amacı yönetici ve öğretmenlerin okullarda karşılaştıkları belirsizlik durumları karşısında verdikleri tepkileri belirlemek ve buna etki eden değişkenleri incelemektir. Bu araştırma bir ölçek geliştirme çalışmasıdır. Pilot uygulamanın evreni Siirt'in Kurtalan ilçesindeki, ikinci uygulamanın evreni ise Siirt il merkezindeki devlet okullarında görev yapan yönetici ve öğretmenlerdir. Uygun örnekleme yöntemi kullanılmıştır. Araştırma verileri, araştırmacı tarafından geliştirilen "Okullardaki Örgütsel Belirsizlik Ölçeği” ile toplanmıştır. Ölçek geliştirme sürecinde; ilk olarak literatür taranmıştır, ardından sorular oluşturularak alan uzmanı görüşü alınmıştır. Açımlayıcı ve doğrulayıcı faktör analizi ile geliştirilen ölçeğin güvenirlik ve geçerliliği test edilmiştir. Bunun sonucunda ölçek, 25 maddeli ve Örgütsel Belirsizliğe Dayalı (ÖBD) Örgütsel Olumsuzluklar, ÖBD Yönetsel Uygulamalar ve ÖBD Bireysel Olumsuzluklar olmak üzere üç boyutlu bir yapıya sahiptir. Elde edilen ölçeğin istenilen teorik yapıyı yüksek oranda ölçtüğü saptanmıştır.

Anahtar Kelimeler: Belirsizlik, Örgütsel Belirsizlik, Okul, Kaos.

\footnotetext{
${ }^{1}$ Makale Geliş/Kabul Tarihi: 25.05.2020 / 15.09.2020

* Bu makale birinci yazar danışmanlı̆̆ında ikinci yazar tarafından hazırlanan “Okullardaki Örgütsel Belirsizlik Düzeyinin Belirlenmesi” başlıklı yüksek lisans tezinden üretilmiștir.

Künye Bilgisi: Toytok, E.H. ve Yavuz, M. (2020). Okullardaki Örgütsel Belirsizlik Düzeyini Belirleme Ölçeği'nin Geliştirilme Çalışması. Kahramanmaraşs Sütçü İmam Üniversitesi Sosyal Bilimler Dergisi, 17 (2), 799-823. DOI: 10.33437/ksusbd.742253
} 


\title{
Study on The Development of Organizational Uncertainty Levels Scale in Schools
}

\begin{abstract}
The purpose of this study is to determine the responses of administrators and teachers against the uncertainties they face in schools and to examine the variables affecting them. This research is a scale development study. The population of the pilot application is the administrators and teachers based in Kurtalan district of Siirt and the population of the second application is the administrators and teachers who work in public schools located in the province of Siirt. The convenience sampling method was used. The data were collected by the "Scale of Organizational Uncertainty in Schools" developed by the researcher. During the scale development process; First, the literature was scanned, then questions were created and opinion of the field expert was taken. The reliability and validity of the scale developed by exploratory and confirmatory factor analysis was tested. As a result, it has a three-dimensional structure with 25 items, including Organizational Uncertainty-Based Negativities (OCD), OCD-Administrative Practices, and OCD Individual Negativities. It was determined that the scale obtained highly measures the desired theoretical structure.
\end{abstract}

Keywords: Uncertainty, Organizational Uncertainty, School, Chaos.

\section{GİRIŞ}

İnsanların bir arada yaşamaya başlamasıyla yaşam koşullarında kaçınılmaz olarak çeşitli değişimler meydana gelmiş, meydana gelen değişmeler hem bireysel hem de toplumsal olarak öngörülebilir ve öngörülemez etkilere neden olmuştur. Aynı zamanda toplumun içindeki formel ve informel yapılar bu değişimlere uyum sağlamaya çalışmaktadır (Aydın, 2014). Aynı insanlar gibi örgütler de bu değişimlerden olumlu ya da olumsuz bir şekilde doğrudan ya da dolaylı bir şekilde etkilenmektedir. Bunun sonucunda örgütlerde yaşanan değişimlere adaptasyon sağlanması sürecinde, işgörenler arasında karmaşa ve kaos ortamları oluşabilmektedir. Örgüt kavramını Barnard (1938), ortak bir amacı gerçekleştirmek için birden fazla kişinin güç ve yeteneklerini birleştirdiği sistemli yapılar olarak tanımlarken, kaos kavramını ise Çinli fizikçi Hao Bai-Lin, periyodikliği olmayan bir düzen türü olarak adlandırmıştır (Gleick, 1996; Eren, 
E.H. Toytok-M. Yavuz Okullardaki Örgütsel Belirsizlik Düzevini...

2020). Örgütlerde oluşan kaotik ortam, ortaya çıkışı esnasında duruma özgü belirsizliklere neden olabilmektedir. Belirsizlik de kaos gibi, örgütlerde doğal olarak ortaya çıkan, örgütün bütün alanlarında etkisini gösteren, olumlu yönlerinin yanı sıra olumsuz tarafları da olan bir durumdur. Nasıl ki fizikte sürtünme görmezden gelinemeyecek bir yap1 ise, evrende de belirsizlik görmezden gelinemeyecek bir yapı olarak kabul edilmesi gereklidir (Armutlulu, 2014). Belirsiz, belirlinin karşıtı olmasının yanı sıra, sadece kesin olanın iyi olduğu görüşü sebebiyle kötü (olumsuz) olarak nitelendirilmektedir (Moles, 2018). Türk Dil Kurumu’na (TDK) göre ise belirsizlik "belirsiz olma durumu, belgisizlik, müphemiyet (anlaşılmazlık) ve vuzuhsuzluk (açık olmama)" olarak açıklanmaktadır. Örgütler değişim durumlarına ya da problemlerine çözüm bulamadıkları zaman belirsizliğe girerler (Tınaztepe, 2010; Polat, 2015). İşte örgüt ortamında yaşanan bu belirsizliğe örgütsel belirsizlik denmektedir. $\mathrm{Bu}$ bağlamda örgütsel belirsizlik kavramını, örgütlerde yaşanan belirli ya da belirsiz süreçlerde, neyin nasıl yapılacağının belli olmaması durumunda ortaya çıkan karmaşa ve kaos olarak tanımlayabiliriz.

Eğitim örgütleri denilince akla gelen ve en yaygın olan kurumlar şüphesiz okullardır. Aynı zamanda okullar açık ve sosyal bir sistem yapısına sahip oldukları için değişimin de en çok yaşandığı örgütlerdir. Sınıf ortamında şekilsel düzenlemelerin yapılması fiziksel değişim kategorisine; öğretim programlarının o günün koşul ve ihtiyaçlarına göre yeniden düzenlenmesi ve sınav sisteminde yapılan değişiklikler ise programsal değişim kategorisine örnek olarak gösterilebilir. Dolayısıyla eğitim kurumlarında yaşanan değişimler Hofstede'in (2011) de belirttiği üzere, hem örgütü oluşturan bireylerde hem de örgütün işleyişinde çeşitli problemlere neden olmaktadır. Örneğin; örgütü oluşturan bireylerde stres veya kaygı seviyesinin yükselmesi gibi olumsuz duygu durumları yaratabilir. Diğer taraftan değişimin açığa çıkardığı dinamizm örgüt için itici ve ateşleyici unsur olarak da karşımıza çıkabildiği görülmektedir (Bakioğlu \& Demiral, 2013; Eren, 2015). Bu nedenle belirsizliklerden kaynaklı olumsuz sonuçların, diğer örgütlerde olduğu gibi okullarda da düzeni bozmak suretiyle kaos ve belirsizlik ortamı yaratması beklenen bir durumdur.

Okul içinde oluşan kaos ortamında doğru kararlar alınabilmesi, ancak belirsizlik durumunun iyi anlaşıımasıyla mümkün olabilmektedir. Karar alma sürecinde, bir okulda bulunan yöneticiler ve öğretmenlerin kaos ortamında gelişen belirsiz durumlar karşısında sergileyecekleri davranışlar bir sonraki aşamada gerçekleşecek olan duruma etki etmektedir. Kaos teorisinde kelebek etkisi olarak adlandırılan bu durum, okullardaki işleyişin gidişatına etki edeceğinden; alınan küçük bir karar dahi büyük oranda önem arz etmektedir. Okul yöneticileri ve öğretmenlerin, mevcut durumu sadece bugünkü şartlara göre değil, geleceği de düşünerek değerlendirmeleri ve davranışlarında esnek olmaları belirsizlik kaynaklı olumsuzlukları en aza indirebilir. $\mathrm{Bu}$ bilinçle ortaya 
çıkabilecek problemleri önlemek için okul yöneticileri ve öğretmenlerin, aldıkları bir kararın etkilerinin neler olabileceğinin farkında olmaları oldukça önemlidir.

Eğitim-öğretim sürecinde oluşan yeni bir durum karşısında okul yöneticilerinin ve öğretmenlerin ne yapacağını bilememesi olumsuz sonuçlara sebebiyet vererek plan programda aksaklıklara, örgüt içinde de belirsizlik durumlarının yaşanmasına neden olacaktır (Clampitt, DeKoch ve Cashman, 2000). Okul ortamında hayatın akışını aksatabilecek bir problem durumu (laboratuvarda cıva gibi insan sağlığına zararlı bir maddenin bulaşı olması) eğitim kurumlarında yaşanan örgütsel belirsizliğe örnek olarak verilebilir. Böylesi durumlarda öğretmen ve yöneticilerin bilgi, tecrübe ve problem çözebilme yetenekleri ön plana çıkar. Sonuç olarak daha önce de belirtildiği üzere bu ve benzeri değişim durumlarında ortaya çıkan belirsizlikler hem eğitim örgütlerini oluşturan bireyler arası iletişimde olumsuz durumlara hem de örgütlerdeki iş ve işleyişte aksamalara sebep olabilecektir. Bunun sonucunda ortaya çıkacak aksamalara bağlı olarak örgüt, hedeflediği amaçlara planladığ ş̧ekilde ve zamanda ulaşamayabilecektir. Bu nedenle örgütlerde ortaya çıkan belirsizliklerin ele alınıp, analiz edilmesi oldukça önem arz eden bir durumdur. Araştırmanın amacı okullardaki örgütsel belirsizlik düzeyini ölçebilecek bir ölçek geliştirmektir. $\mathrm{Bu}$ bağlamda ilgili literatür incelendiğinde; Tınaztepe (2010) tarafından işletmelerde belirsizlik düzeyini belirlemeye yönelik ölçek uyarlamasının yapıldığı, Uz (2015) tarafından hayatın genelinde yaşanan belirsizlik düzeyini ölçmek amacıyla ölçek uyarlamasının yapıldığı ve Dağdaş (2018) tarafından ise eğitim ortamında öğrencilerin yaşadığı belirsizlik düzeyini belirmeye yönelik ölçek geliştirildiği görülmüsstür. Ancak okul ortamındaki öğretmen ve yöneticilerin yaşaması muhtemel belirsizlik durumlarına verdikleri tepkiyi inceleyen herhangi bir çalışmaya ulaşılabilen kaynaklarla sınırlı kalmak kaydıyla rastlanılmamıştır. $\mathrm{Bu}$ nedenle araştırma sonucunda geliştirilecek okullarda örgütsel bilirsizlik ölçeği ile hem bilimsel alandaki akademik bir boşluğu doldurmak, hem de okullardaki örgütsel belirsizliği belirleyerek azaltmak amaçlanmaktadır.

\section{YÖNTEM}

\section{Araştırma Modeli}

$\mathrm{Bu}$ araştırma bir ölçek geliştirme çalışmasıdır. Okullardaki örgütsel belirsizlik düzeyini belirleme ölçeği (OÖBÖ) geliştirilmesinde izlenen süreçler ve çalışma grubuna ait özellikler aşağıda sunulmuştur.

\section{Evren ve Örneklem}

Araştırmada iki uygulama yapıldığ düzenlenmiştir. Bu çalışma 2018-2019 eğitim öğretim yılında resmi Anaokul 
$\underline{\text { E.H. Toytok-M. Yavuz } \quad \text { Okullardaki Örgütsel Belirsizlik Düzeyini... }}$

ilkokul, ortaokul ve lisede görev yapan öğretmenlere uygulanmıştır. İlk uygulama Siirt ili Kurtalan ilçesinde ikinci uygulama ise il merkezinde yapılmıştır. İlk uygulamaya ilişkin evren olarak Kurtalan ilçesi seçilmiştir. Kurtalan ilçesinin evrenini 118 eğitim kurumu ve 959 yönetici-öğretmen oluşturmaktadır. İlk uygulamada Kurtalan'da öğretmen ve yöneticilere toplam 780 ölçek dağıtılmış olup bunlardan 665 tanesinin geri dönüşü sağlanmıştır. Geri dönen ölçeklerden 101 tanesi yönergeye uygun doldurulmadığı için araştırma kapsamı dışında bırakılarak 564 ölçek araştırmaya dâhil edilmiştir. İlk uygulamaya ilişsin örneklem bilgileri Tablo 1'de sunulmuştur.

Tablo 1. Birinci Uygulamanın Örneklemine İlişkin Bilgiler

\begin{tabular}{lcc} 
& Frekans (n) & $\%$ \\
\hline Cinsivet & & \\
Kadın & 248 & 44.0 \\
Erkek & 316 & 56.0 \\
Görev & & \\
Müdür & 35 & 6.2 \\
Müdür Yardımcısı & 59 & 10.5 \\
Öğretmen & 470 & 83.3 \\
Brans & & \\
Okul Öncesi Öğretmeni & 41 & 7.2 \\
Sinıf Öğretmeni & 134 & 23.8 \\
Branș Ŏgretmeni & 389 & 69.0 \\
Okul Seviyesi & & \\
Anaokulu & 34 & 6 \\
İlkokul & 163 & 28.9 \\
Ortaokul & 195 & 34.6 \\
$\quad$ Lise & 172 & 30.5 \\
\hline Toplam & 564 & 100
\end{tabular}

İlk uygulamada Yazıcıŏglu ve Erdoğan'ın örneklem büyüklüğü hesaplamak üzere geliştirdikleri tabloya göre; $\alpha=0.05$ anlamlılık düzeyindeki hesaplamalar için 0.04 sapma miktarı (örnekleme hatası) baz alındığında 375 kişiden oluşan örneklem büyüklügü hesaplamaları genellemek için yeterli gelmektedir (Akt: Sönmez ve Alacapınar, 2014). Bu bağlamda alınan 564 kişilik örneklem büyüklüğü evreni temsil etmekte yeterli olarak kabul edilebilir.

Araştırmanın ikinci uygulamasının evrenini Siirt il merkezindeki resmi okullar (anaokulu, ilkokul, ortaokul ve liseler) oluşturmaktadır. Bu 139 okulda toplam 2166 yönetici-öğretmen görev yapmaktadır. Araştırmada Siirt il merkezindeki okullara toplam 1550 ölçek dağıtılmış olup, bu ölçeklerin 1399 tanesi geri dönmüştür. Geri dönüşü sağlanan 528 ölçek yönergeye uygun doldurulmadığından araştırma kapsamı dışında bırakılarak 871 ölçek araştırmaya 
dâhil edilerek analiz edilmiştir. İkinci uygulamaya ilişkin örneklem bilgileri Tablo 2'de sunulmuştur.

Tablo 2. İkinci Uygulamanın Örneklemine İlişkin Bilgiler

\begin{tabular}{lcc} 
& Frekans (n) & $\%$ \\
\hline Cinsivet & 375 & \\
Kadın & 496 & 43 \\
Erkek & & 57 \\
Görev & 41 & 4.7 \\
Müdür & 96 & 11 \\
Müdür & 734 & 84.3 \\
Öğretmen & & \\
Brans & 298 & 34.3 \\
Sözel & 172 & 19.7 \\
Sayısal & 325 & 37.3 \\
Eșit Ağırlık & 76 & 8.7 \\
Yetenek & & \\
Okul Seviyesi & 54 & 6.2 \\
Anaokulu & 257 & 29.5 \\
İlkokul & 272 & 31.2 \\
Ortaokul & 257 & 29.5 \\
Lise & 31 & 3.6 \\
Özel Eğitim & 871 & 100 \\
\hline Toplam & &
\end{tabular}

İkinci uygulamada da Yazıcıŏglu ve Erdoğan'ın örneklem büyüklüğü hesaplamak üzere geliştirdikleri tabloya göre; $\alpha=0.05$ anlamlılık düzeyindeki hesaplamalar için 0.03 sapma miktarı (örnekleme hatası) baz alındığında 787 kişiden oluşan örneklem büyüklüğü hesaplamaları genellemek için yeterli gelmektedir (Yazıcıoğlu ve Erdoğan, 2004; Sönmez ve Alacapınar, 2014). Bu bağlamda alınan 871 kişilik örneklem büyüklügü evreni temsil etmekte yeterli olarak kabul edilebilir.

\section{Veri Toplama Aracının Geliştirilmesi}

Okullardaki örgütsel belirsizlik düzeyini belirleme ölçeği (OÖBÖ) geliştirilmesi çalışmasında ilk aşamasında konuyla ilgili gerekli literatür taraması yapılarak, alan yazındaki araştırmalar incelenmiştir. Ardından kuramsal çerçeveye bağlı olarak geliştirilmek istenilen ölçeğe ilişkin 47 maddelik bir havuz oluşturulmuştur. Madde havuzundaki soruların uzman görüşleri alınarak 39 maddelik bir yapıya ve uygun cümle yapılarına dönüştürülmüştür. Elde edilen 39 maddelik OÖBÖ’nin anlaşılırlığı ve görünüş geçerliliğinin belirlenmesi için bilişsel görüşme uygulaması farklı branşlarda 8 öğretmen ile yapılmıştır. Bilişsel 
görüşme yapılan öğretmenlerden gelen geribildirimlere göre, ölçeğin son şekli verilmiştir. Bilişsel görüşme, yeni yeni yaygınlaşmaya başlayan ve amacı katılımcıların ölçek sorularına cevap verirken kullandıkları bilişsel süreçlere açık bir şekilde odaklanmak ve bu süreçleri anlamak olan bir yöntemdir (Willis, 1999). Bilişsel görüşme; kişiye yöneltilen sorunun kapsamı, hafızadaki bilginin geri çağnılması, karar süreçleri ve cevap verme süreçleri olmak üzere dört aşamadan oluşan bir yapıya sahiptir (Toytok ve Doğan, 2019). Ölçekte yer alan maddelerin araştırmada ulaşılmak istenen yapıya hizmet edip-etmediği, katılımcıda ne anlam ifade ettiği, katılımcının maddelerden hangi anlamlar çıkardığ1 ve maddeleri okurken anlamada zorlanıp-zorlanmadığ1 gibi sorular bilişsel görüşme uygulaması sayesinde yanıtlanmaktadır. Yapılan bu uygulama sonrasında ortaya çıkan eleştirilere ek olarak yeniden uzman görüşleri alınmak suretiyle ölçeğin birinci uygulamada kullanılacak şekli oluşturularak Siirt ili Kurtalan ilçesinde uygulanmıştır. Birinci uygulama sonucunda OÖBÖ’nde ki 39 madde 34'e indirilerek, Siirt Merkezinde ikinci uygulaması yapılmıştır. Bu uygulamanın sonucunda ölçeğe son şekli verilerek 25 maddelik ve üç faktörlü yapısı oluşturulmuştur. Aşamalarla ilgili detaylı bilgiler ve tablolar bulgular bölümünde sunulmuştur. OÖBÖ dörtlü derecelendirilmiştir ve birden dörde kadar numaralandırılarak; $1,2,3$ ve 4 değerleri sıralı-kategorik yapıda olsa da eşit aralıklı olduğu (1= Hiçbir zaman, 2= Ara Sıra, 3= Siklıkla, 4= Her zaman) varsayılmıştır. 4'lü derecelendirmede 3 skala aralığ bölünmesiyle (3/4=.75) aralığı bulunmuştur.

\section{Geçerlilik ve Güvenirlilik Çalışmaları}

OÖBÖ’nin geçerlilik yapısını güçlendirmek için öncelikle ölçeğin ilk uygulamasında elde edilen verilerin açımlayıcı faktör analizi (AFA) ve FIT model uyumluluk değerleri kontrol edilmiştir. Yapılan analiz sonucunda ölçeğin 34 maddelik formu 25 maddeye indirgenerek 3 faktörlü yapıda ölçmek istenilen teorik yapıyı en uygun şekilde açıkladığı görülmüştür. Geliştirilen 25 maddelik son ölçek formu ilk uygulama yerinden farklı bir bölgede tekrar uygulanarak, elde edilen yeni değerlere ilişkin AFA, FIT ve doğrulayıcı faktör analizi (DFA) istatistiki prosedürleri uygulanarak kontrol edilmiştir.

\section{Verilerin Analizi}

Araştırmada geliştirilen 3 faktörlü 25 maddelik OÖBÖ’nin birinci ve ikinci uygulama /dönüştürme sürecine ilişkin elde edilen bilgiler, araştırmanın bulgular bölümünde sunulmuştur. Analiz için veriler, R. 3.3.1 stüdyo programında (R Core Team, 2016) düzenlenmiştir. Verilerin analizi M Plus 7 programında gerçekleştirilmiştir (Muthen \& Muthen, 1998-2015). Verilerin sıralandırılmış ölçekle toplanmış olduğu göz önüne alarak ağırlıklandırılmış en küçük kareler faktör analitik tekniği kullanılarak açımlayıcı faktör analizi (AFA) ve sonrasında 
doğrulayıcı faktör analizi (DFA) gerçekleştirilmiştir. Boyutların birbiriyle ilişkili olduğu sayıltısı ile hareket edilerek, ölçekte bulunan toplam faktör sayısı, açıklanan varyans, istatistiksel uyum ve faktör yükleri göz önüne alınarak belirlenmiştir. Bu şekilde belirlenen yapıya teorik olarak açılama getirilmeye çalışılmıştır.

Her adımda model veri uyumu Ki-kare (Kline, 2015), Karşılaştırmalı Uyum İndeksi (CFI) (Bentler, 1990), Tucker ve Levis'in Uyum İndeksi (TLI) (Tucker ve Lewis, 1973) ve Yaklaşık Ortalama Karekök Hatası (RMSEA) (Steiger, 1990) istatistikleri ile belirlenmiştir. Ki-kare değeri model-veri uyumsuzluğunu ifade eder ancak örneklem büyüklüğü arttıkça ki-kare değeri uyumsuzluğun miktarını daha da fazla gösterir (Kline, 2015). Bu nedenle ki-kare değerleri sadece aynı örneklemle oluşturulan farklı modellerin karşılaştırılmasında kullanılmıştır. Madde ile boyut arasında ortak \%16'lk bir varyans varsa o madde ile boyutu ilişkili kabul edilmiştir. Bu nedenle faktör yükleri değerlendirilirken, madde ile bulunduğu faktör arasındaki ilişki mutlak değerdeki faktör yükünün .40 'tan daha büyük olması durumunda o madde boyutla ilişkili olduğu kabul edilmiş, .40'ın altındaki değere sahip maddeler ölçekten çıkartılmıştır. Güvenirlik indeksi olarak faktör analizinde ortaya çıan her bir boyut için Cronbach Alfa (Cronbach, 1951) iç tutarlılık indeksi ve Raykov's $\rho$ değeri kullanılmıştır.

\section{BULGULAR}

Bu bölümde Okullarda Örgütsel Belirsizlik Ölçeği’nin (OÖBÖ) geçerlik ve güvenirlik çalışmalarından elde edilen bulgulara yer verilmiştir.

Birinci Uygulamaya ilişkin Uyum İstatistikleri, Açımlayıcı Faktör Analizi (AFA) ve Doğrulayıcı Faktör Analizi (DFA)

Araştırmada elde edilen verilere dayalı FIT istatistik değerleri Tablo 4'te sunulmuştur. Bu tabloda ele alınan değerler için Hu ve Bentler'e (1999) göre Karşılaştırmalı Uyum İndeksi (CFI) ve Trucker ve Lewis' in Uyum İndeksi (TLI) değerlerinin ne kadar .95 ve üstü ise araştırma o kadar iyi modellenmekte olduğunu, Browne ve Cudeck' e (1993) göre, RMSEA değeri ne kadar .050 ve altında ise o kadar uyumun arttığını, Bentler ve Bonett (1980) .90' in altı CFI ve TLI değerlerine sahip modellerin azımsanmayacak derecede geliştirilebilir olduğunun ifade etmektedirler.

Tablo 3'teki veriler incelendiğinde son yapılan üç faktörlü çözüm modelinin teorik anlamlılık, açıklanan varyans, faktör yükleri incelendiğinde, ayrıca modelin istatiksel uyum değerleri referans aralıklarına göre değerlendirildiğinde, modelin kabul edilebilir bir uyum gösterdiği görülmektedir. Bu sonuçlara göre üç faktörlü çözüm modeli, ölçek için en uygun model olarak belirlenmiştir. Bu üç faktörlü yapının özdeğer yüklerine bakıldığında \%48 $(18.810 \div 39=.48)$ gibi 
yüksek bir açımlayıcılığa sahip olduğu görülmüştür. Ancak ölçekteki 3 faktörün her hangi birisiyle ilişkili bulunmayan 6 madde çıkartılarak geriye kalan 33 madde ile 3 faktörlü yapı için, hesaplanan serbest parametre başına düşen gözlem sayısı $(564 \div 96=5.87$ gözlem) gerekli koşulu sağlamaktadır (Bentler \& Chou, 1987). Bu üç faktörlü yapının özdeğer yükleri ise $\% 54(17.714 \div 33=.54)$ gibi yüksek bir açımlayıcılığa sahiptir. Tablo 3 incelendiğinde verilere göre en ideal modellemenin üç faktörlü yapıda oluştuğu görülmüştür.

Tablo 3. Birinci Uygulama Uyum İstatistikleri Özeti Tablosu

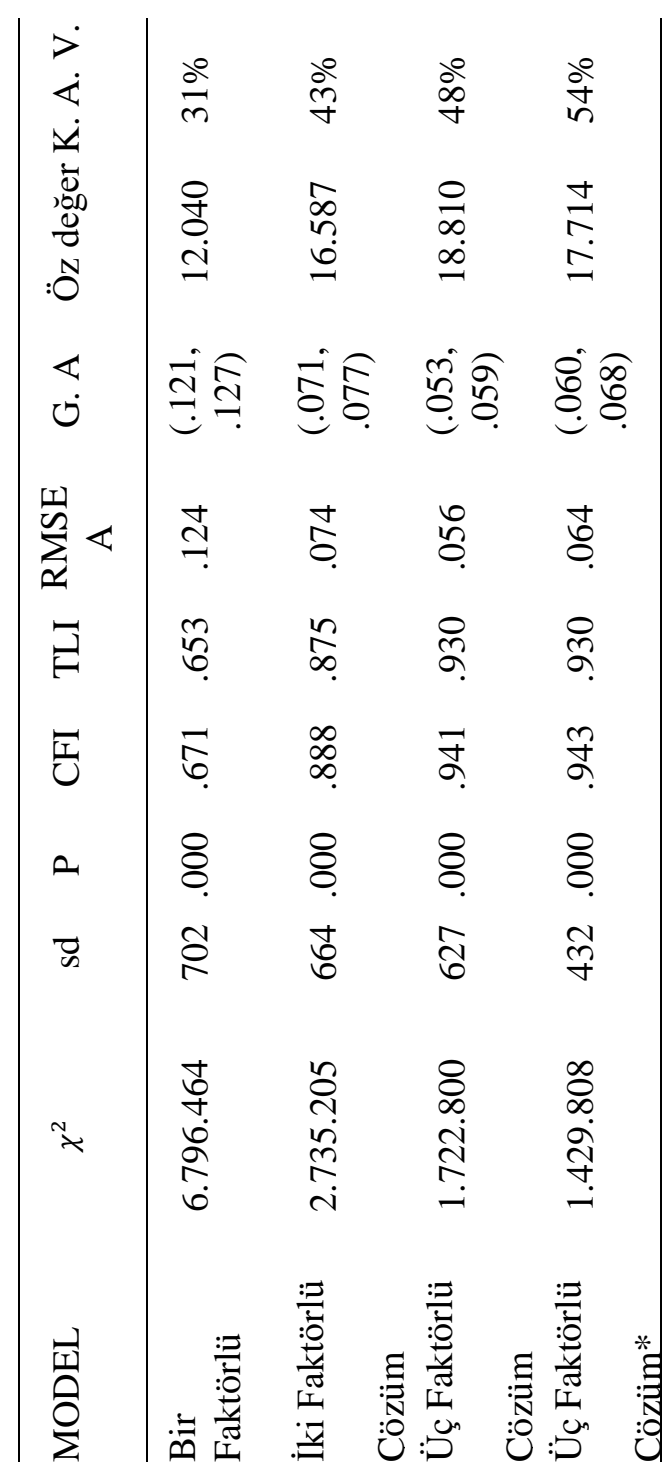


Araştırmanın birinci uygulamasında elde edilen verilere dayalı Açımlayıcı Faktör Analizi (AFA) sonuçları Tablo 4'te sunulmuştur.

Tablo 4. Birinci Uygulama İçin Açımlayıcı Faktör Analizi Üç Boyutlu Çözüm Faktör Yükleri

\begin{tabular}{|c|c|c|c|c|}
\hline & Okullardaki Örgütsel Belirsizlik Ölçeği & 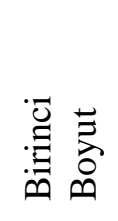 & 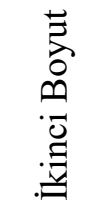 & 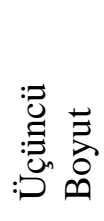 \\
\hline & OKULUMDA; & & & \\
\hline 1. & $\begin{array}{l}\text { Belirsizlik durumlarına uyum sağlamak için } \\
\text { değişim yaşanır. }\end{array}$ & .505 & .251 & -.007 \\
\hline 2. & $\begin{array}{l}\text { Mevcut bir durum değiştiğinde, öğretmenler } \\
\text { arasında bu değişim sorgulanır. }\end{array}$ & .377 & .286 & -.017 \\
\hline 3. & $\begin{array}{l}\text { Öğretmen ve yöneticilerin görev dağılımı açık- } \\
\text { net bir şekilde yapılır. }\end{array}$ & .600 & -.047 & -.047 \\
\hline 4. & $\begin{array}{l}\text { Performans değerlendirme standartları } \\
\text { öğretmenlerle paylaşılır. }\end{array}$ & .550 & -.025 & -.022 \\
\hline 5. & $\begin{array}{l}\text { Öğretmenler, belirsizlik durumlarına özgün } \\
\text { çözüm önerileri getirmeleri için teşvik edilir. }\end{array}$ & .753 & -.001 & -.025 \\
\hline 6. & $\begin{array}{l}\text { Yaşanan belirsizlik, örgüt içindeki iletişimin } \\
\text { bozulmasına neden olur. }\end{array}$ & -.005 & .477 & .075 \\
\hline 7. & $\begin{array}{l}\text { Çevresel faktörler, karar verme sürecini } \\
\text { (olumsuz yönde) etkiler. }\end{array}$ & -.014 & .530 & .050 \\
\hline 8. & $\begin{array}{l}\text { Belirsizlik yaşanması, okul yöneticilerinin } \\
\text { harekete geçmesini engeller. }\end{array}$ & .005 & .739 & .005 \\
\hline 9. & $\begin{array}{l}\text { Yaşanan belirsizlik, okul yöneticilerinin karar } \\
\text { alma sürecini (olumsuz yönde) etkiler. }\end{array}$ & .055 & .853 & .020 \\
\hline 10. & $\begin{array}{l}\text { Belirsizlik yaşanması durumunda, okul } \\
\text { yönetiminin tüm alanlardaki etkililiği azalır. }\end{array}$ & -.093 & .644 & .086 \\
\hline 11. & $\begin{array}{l}\text { Belirsizlik ortamında alınan kararlar, tekrar } \\
\text { gözden geçirilir. }\end{array}$ & .576 & .193 & -.024 \\
\hline 12. & $\begin{array}{l}\text { Oluşan belirsizlik durumlarını gidermek adına } \\
\text { çaba gösteririm. }\end{array}$ & .553 & .130 & -.068 \\
\hline 13. & $\begin{array}{l}\text { Yaşanan her belirsizlik durumu karşısında, } \\
\text { kaygılanırım. }\end{array}$ & .093 & .010 & .860 \\
\hline 14. & $\begin{array}{l}\text { Yaşanan her belirsizlik durumu karşısında, stres } \\
\text { yaşarım. }\end{array}$ & .071 & -.002 & .926 \\
\hline
\end{tabular}




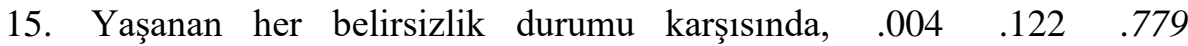
korkarım.

16. Yaşanan her belirsizlik durumu karşısında, $\begin{array}{rllll}-.049 & .036 & .703\end{array}$ kararsızlık yaşarım.

$\begin{array}{lllll}\text { 17. Karşılaştığım belirsizlik durumları bende şok } & -.008 & .143 & .647\end{array}$ etkisi yaratır.

18. Belirsizlik yaşanması iş motivasyonumu etkiler. $\quad \begin{array}{llll}.015 & .119 & .558\end{array}$ OKUL YÖNETICILERIMIZ;

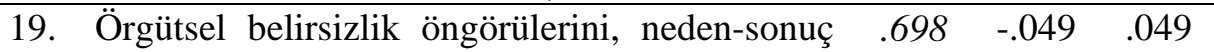
ilişkisi içerisinde yapabilmede yeterlidir.

20. Okulun sadece bugününü değil; aynı zamanda $\begin{array}{llll}.768 & -.072 & .036\end{array}$ yarınlarını da yönettiklerinin farkındadır.

21. Okulda ortaya çıkan belirsizliğin yönetim $\begin{array}{llll}\text { 807 } & -.104 & .066\end{array}$ sürecinde, öğretmenlere yardımcı olur.

$\begin{array}{llllll}\text { 22. Örgütsel belirsizlikle başa çıma yollarını } & .788 & .002 & .012\end{array}$ aramada öğretmenlerden destek alır.

$\begin{array}{llllll}\text { 23. Belirsizlik durumlarında, yeni fikirler } & .841 & -.017 & .025\end{array}$ oluşmasına imkan sağlar.

24. Okuldaki belirsizliğin giderilmesinde, en uygun $\quad \begin{array}{llll}.780 & -.192 & .100\end{array}$ yöntemleri seçmede yeterlidir.

$\begin{array}{llllll}\text { 25. Örgütsel belirsizliği giderme sürecinde } & .741 & -.034 & .055\end{array}$ öğretmenlere anında geribildirim sağlar.

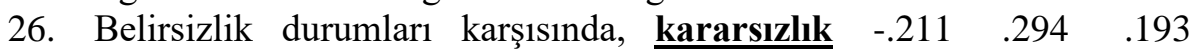
yaşar.

$\begin{array}{lllllll}\text { 27. Belirsizlik durumlarında aldığ } & \text { her kararda } & -.135 & .385 & .042\end{array}$ çevrenin tepkilerinden etkilenir.

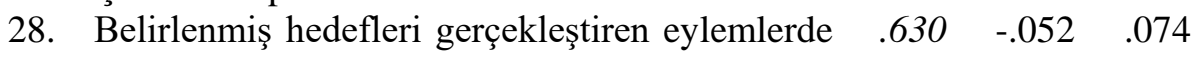
bulunur.

$\begin{array}{lllll}\text { 29. Örgütsel belirsizlik durumunda ihtiyaç duyulan } & .714 & -.138 & .074\end{array}$ liderlik davranışlarını göstermede yeterlidir.

\section{BENCE;}

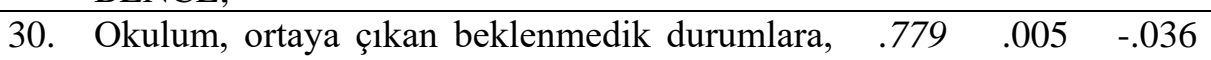
yeterince uyum sağlayabilir.

$\begin{array}{llllll}\text { 31. Öğretmenler okulumuzun geleceği ile ilgili } & .608 & .057 & -.178\end{array}$ beklentileri, açık ve net bir şekilde biliyor.

$\begin{array}{llll}\text { 32. Okulum, meydana gelen değişimler karşısında } & .783 & .043 & -.146\end{array}$ denge kurmakta yeterince başarılıdır.

33. Çalıştığım okulda örgüt kültürü hissedilir. $\quad \begin{array}{llll}663 & .026 & -.099\end{array}$

$\begin{array}{lllll}\text { 34. Çalıştığım okulun örgüt kültürü ile uyuşmazlık } & -.160 & .219 & .131\end{array}$ yaşadığım zamanlar olur.

$\begin{array}{llll}\text { 35. Okul ortamında yaşanan her belirsizlik olumsuz } & -.010 & .322 & .235\end{array}$ bir durumdur. 
36. Öğretmenler, oluşan belirsizlik durumlarında $\begin{array}{llll}.598 & .205 & -.142\end{array}$ birlikte hareket edebilir.

37. Öğretmenler, karşılaştıkları belirsizlik $\quad .597 \quad .160 \quad-.192$ durumlarında sağliklı karar verebiliyor.

38. Örgütsel belirsizlik durumlarını görmezden $\begin{array}{llll}.152 & .267 & .057\end{array}$ gelmek, örgüt için olumsuz bir durum yaratır.

39. Okulumda belirsiz bir ortamda çalışıyorum. $\quad \begin{array}{llll}-.432 & .196 & .202\end{array}$

Not: ÖBD Yönetsel Uygulamaların Cranbach Alpha güvenirlik katsayısı .930, ÖBD Örgütsel Olumsuzlukların Cranbach Alpha güvenirlik katsayısı .767, ÖBD Bireysel Olumsuzlukların Cranbach Alpha güvenirlik katsayısı ise .856 olarak hesaplanmiştır.

Tablo 4'teki veriler incelendiğinde madde ile boyut arasında ortak \% 16 ' lik bir varyans varsa o madde ile boyutu ilişkili kabul edilmiştir. Dolayısıyla faktör yükleri değerlendirilirken, madde ile bulunduğu faktör arasındaki ilişki mutlak değerdeki faktör yükünün .40 'tan daha büyük olması durumunda o madde boyutla ilişkilendirilmiştir, hiçbir boyutla ilişkili olmayan maddeler ise bu nedenle ölçekten çıkartılmıştır (Kenny vd., 2006).Buna bağlı olarak AFA üç boyutlu çözüme göre $1,3,4,5,11,12$, 19, 20, 21, 22, 23, 24, 25, 28, 29, 30, 31, 32, 33, 36, 37 ve 39. maddelerin ağırlıklı olarak birinci boyut, 6, 7, 8, 9 ve 10. maddelerin ikinci boyut, 13,14, 15, 16, 17 ve 18. maddelerin ağırlıklı olarak üçüncü boyut tarafindan yüklendiği tespit edilmiştir. Bu faktörlerin toplandığ maddeler incelenerek uygun isimlendirme yapılmıştır. Boyutlara uygun isimlendirme yapılırken; öncelikle her boyutta yer alan maddelerin ortak olarak ele aldıkları konular belirlenmiştir. Literatürde yer alan belirsizliğe ilişkin alt boyutlar ve çeşitli belirsizlik kaynağı sınıflandırmaları göz önünde bulundurularak, olabilecek boyut isimleri listelenmiştir. Ardından alan uzmanlarının da listedeki boyut isimleri ile ilgili görüşleri alınarak uygun olan isimler belirlenmiştir. Birinci boyut "Örgütsel Belirsizliğe Dayalı Yönetsel Uygulamalar” (ÖBD-YU), ikinci boyut "Örgütsel Belirsizliğe Dayalı Örgütsel Olumsuzluklar" (ÖBD-ÖO) ve üçüncü boyut ise "Örgütsel Belirsizliğe Dayalı Bireysel Olumsuzluklar” (ÖBD-BO) olarak isimlendirilmiştir. Boyutlara ait Cronbach Alpha değerleri hesaplanarak Tablo 4'ün alt notunda, Raykov's $\rho$ değerleri ise hesaplanıp boyutların isimlerinin yanına yazılarak Tablo 4'te verilmiştir.

Araştırmanın birinci uygulamasında elde edilen verilere dayalı Doğrulayıcı Faktör Analizi (DFA) sonuçları Tablo 5’te sunulmuştur. 
E.H. Toytok-M. Yavuz Okullardaki Örgütsel Belirsizlik Düzeyini...

Tablo 5. Birinci Uygulama İçin Doğrulayıcı Faktör Analizi (DFA)

\begin{tabular}{|c|c|c|c|c|c|}
\hline & Okullardaki Örgütsel Belirsizlik Ölçeği & 党 & & t & $\mathbf{p}$ \\
\hline \multicolumn{6}{|c|}{ ÖBD Örgütsel Olumsuzluklar (Raykov’s $\rho=.823$ ) } \\
\hline & $\begin{array}{l}\text { Okulumda yaşanan belirsizlik, örgüt } \\
\text { içindeki iletișimin bozulmasina neden olur. }\end{array}$ & .546 & .043 & 12.713 & .000 \\
\hline 7. & $\begin{array}{l}\text { Okulumda çevresel faktörler, karar verme } \\
\text { sürecini (olumsuz yönde) etkiler. }\end{array}$ & .564 & .044 & 12.925 & .000 \\
\hline 8. & $\begin{array}{l}\text { Okulumda belirsizlik yaşanması, okul } \\
\text { yöneticilerinin harekete geçmesini } \\
\text { engeller. }\end{array}$ & .740 & .034 & 21.542 & .000 \\
\hline & $\begin{array}{l}\text { Okulumda yaşanan belirsizlik, okul } \\
\text { yöneticilerinin karar alma sürecini } \\
\text { (olumsuz yönde) etkiler. }\end{array}$ & .803 & .028 & 28.800 & .000 \\
\hline \multirow[t]{3}{*}{10.} & belirsizlik & .793 & .033 & 24.148 & .000 \\
\hline & $\begin{array}{l}\text { durumunda, okul yönetiminin tüm } \\
\text { alanlardaki etkililiği azalır. }\end{array}$ & & & & \\
\hline & \multicolumn{5}{|c|}{ ÖBD Yönetsel Uygulamalar(Raykov’s $\rho=.942$ ) } \\
\hline & $\begin{array}{l}\text { Belirsizlik durumlarına uyum sağlamak } \\
\text { için değişim yaşanır. }\end{array}$ & .391 & .039 & 9.889 & .000 \\
\hline 3. & $\begin{array}{l}\text { Okulumda öğretmen ve yöneticilerin görev } \\
\text { dağılımı açık-net bir şekilde yapılır. }\end{array}$ & .636 & .031 & 20.342 & .000 \\
\hline 4. & $\begin{array}{l}\text { Okulumda performans değerlendirme } \\
\text { standartları öğretmenlerle paylaşılır. }\end{array}$ & .571 & .031 & 18.424 & .000 \\
\hline 5. & $\begin{array}{l}\text { Okulumda öğretmenler, belirsizlik } \\
\text { durumlarına çözüm önerileri getirmeleri } \\
\text { için teşvik edilir. }\end{array}$ & .759 & .020 & 37.458 & .000 \\
\hline 11. & $\begin{array}{l}\text { Belirsizlik ortamında alınan kararlar, tekrar } \\
\text { gözden geçirilir. }\end{array}$ & .500 & .035 & 14.198 & .000 \\
\hline 12. & $\begin{array}{l}\text { Oluşan belirsizlik durumlarını gidermek } \\
\text { adına çaba gösteririm. }\end{array}$ & .520 & .035 & 14.198 & .000 \\
\hline 19. & 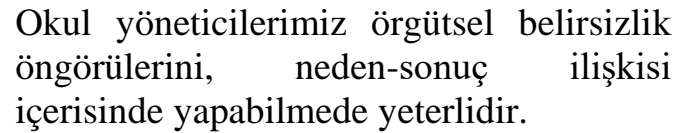 & .697 & .026 & 27.216 & .000 \\
\hline 20. & $\begin{array}{l}\text { Okul yöneticilerimiz okulun sadece } \\
\text { bugününü değil; aynı zamanda yarınlarını } \\
\text { da yönettiklerinin farkındadır. }\end{array}$ & .780 & .020 & 38.230 & .000 \\
\hline
\end{tabular}


21. Okul yöneticilerimiz okulda ortaya çıkan

$\begin{array}{llll}.825 & 017 & 47.149 & .000\end{array}$ belirsizliğin yönetim sürecinde, öğretmenlere yardımcı olur.

22. Okul yöneticilerimiz örgütsel belirsizlikle başa çıkma yollarını aramada ögretmenlerden destek alır.

23. Okul yöneticilerimiz belirsizlik durumlarında, yeni fikirler oluşmasına imkan sağlar.

24. Okul yöneticilerimiz okuldaki belirsizliğin giderilmesinde, en uygun yöntemleri seçmede yeterlidir.

25. Okul yöneticilerimiz örgütsel belirsizliği giderme sürecinde öğretmenlere anında geribildirim sağlar.

28. Okul yöneticilerimiz belirlenmiş hedefleri gerçekleştiren eylemlerde bulunur.

29. Okul yöneticilerimiz örgütsel belirsizlik durumunda ihtiyaç duyulan liderlik davranışlarını göstermede yeterlidir.

30. Bence okulum, ortaya çıkan beklenmedik durumlara, yeterince uyum sağlayabilir.

31. Bence öğretmenler okulumuzun geleceği ile ilgili beklentileri, açı ve net bir şekilde biliyor.

32. Okulum, meydana gelen değişimler karşısında denge kurmakta yeterince başarılıdır.

33. Bence çalıştığım okulda örgüt kültürü hissedilir.

36. Öğretmenler, oluşan belirsizlik .559

$\begin{array}{llll}.782 \quad .019 & 40.175 \quad .000\end{array}$

$\begin{array}{llll}.840 \quad 016 \quad 53.254 & .000\end{array}$

$\begin{array}{llll}.823 & .017 \quad 47.389 & .000\end{array}$

$\begin{array}{llll}.737 & .022 & 33.161 \quad .000\end{array}$

$\begin{array}{llll}.624 & .030 & 20.877 & .000\end{array}$

$\begin{array}{llll}.743 \quad 024 & 31.527 \quad 000\end{array}$ durumlarında birlikte hareket edebilir.

37. Öğretmenler, karşılaştıkları belirsizlik $\quad .593 \quad .031 \quad 19.424 \quad .000$ durumlarında sağlıklı karar verebiliyor.

$\begin{array}{lllllll}\text { 39. Okulumda belirsiz bir ortamda } & -.568 & .034 & -16.876 & .000\end{array}$ çalışıyorum.

ÖBD Bireysel Olumsuzluklar (Raykov's $\rho=.904$ )

$\begin{array}{lllll}\text { 13. Okulumda yaşanan her belirsizlik durumu } & .832 & .017 & 48.015 & .000\end{array}$ karşısında, kaygılanırım.

14. Okulumda yaşanan her belirsizlik durumu $\quad \begin{array}{llll}893 & .015 & 60.206 & .000\end{array}$ karşısında, stres yaşarım. 
15. Okulumda yaşanan her belirsizlik durumu $\quad \begin{array}{lllll}840 & .018 & 46.934 & 000\end{array}$ karşısında, korkarım.

16. Okulumda yaşanan her belirsizlik durumu $\quad \begin{array}{llll}739 & .025 & 29.957 & .000\end{array}$ karşısında, kararsızlık yaşarım.

$\begin{array}{lllllll}\text { 17. Okulumda } & \text { karşılaştı ğım } & \text { belirsizlik } & .730 & .028 & 25.650 & .000\end{array}$ durumları bende şok etkisi yaratır.

18. Belirsizlik yaşanması iş motivasyonumu $\quad .641 \quad 032 \quad 20.316 \quad .000$ etkiler.

Not: ÖBD Yönetsel Uygulamaların faktör puanları ile ÖBD Örgütsel Olumsuzlukların faktör puanları arasındaki korelasyon $r=-.358$, ÖBD Bireysel Olumsuzlukların faktör puanları ile ÖBD Örgütsel Olumsuzlukların faktör puanları arasındaki korelasyon $r=.428$, ÖBD Bireysel Olumsuzlukların faktör puanları ile ÖBD Yönetsel Uygulamaların faktör puanları arasındaki korelasyon ise $r=-.257$ olarak kestirilmiştir.

Tablo 5 incelendiğinde ÖBD Bireysel Olumsuzluklar boyutunda yer alan 14 . Maddenin (Std. faktör yükü .893) en yüksek faktör yüküne sahip olan madde olduğu görülmektedir. Boyutların faktör puanları arasındaki korelasyon değerleri incelendiğinde; en yüksek korelasyonun .428 değeri ile ÖBD Bireysel Olumsuzluklar ve ÖBD Örgütsel Olumsuzluklar boyutlarının faktör puanları arasında, en düşük korelasyonun ise - .358 değeri ile ÖBD Yönetsel Uygulamalar ve ÖBD Örgütsel Olumsuzluklar boyutlarının arasında olduğu görülmektedir.

\section{İkinci Uygulamaya ilişkin Uyum İstatistikleri, Açımlayıcı Faktör Analizi (AFA) ve Doğrulayıcı Faktör Analizi (DFA)}

Araştırmanın ikinci uygulamasında yapılan AFA'ya ait ki kare değeri (3155.301), serbestlik derecesi (432), CFI değeri (.916) ve TLI değeri (.897) ve .082-.088 güven aralığı ile RMSEA değeri (.085) Tablo 2.3 göz önüne alınarak incelendiğinde;CFI ve RMSEA değerlerine göre kabul edilebilir bir eylem modeli uyumu olmasına rağmen TLI değeri kabul edilebilir sınırın biraz altında kalmaktadır. Model, hesaplanan serbest parametre başına en az beş gözlem koşulunu sağlamakta $(871 \div 125=6.97$ gözlem $)$, ayrıca teorik olarak da uygunluk koşulunu sağlamaktadır (Bentler \& Chou, 1987).

Araştırmanın ikinci uygulaması sonucunda elde edilen verilere göre yapılan Açımlayıcı Faktör Analizi sonuçları Tablo 6'da sunulmuştur. 
Tablo 6. İkinci Uygulama İçin Açımlayıcı Faktör Analizi Üç Boyutlu Çözüm Faktör Yükleri

\begin{tabular}{|c|c|c|c|c|}
\hline & Okullardaki Örgütsel Belirsizlik Ölçeği & $\begin{array}{l}0 \\
: 0 \\
1 \\
\hat{⿵} \\
0\end{array}$ & 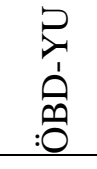 & $\begin{array}{l}0 \\
n \\
\dot{1} \\
0 \\
0\end{array}$ \\
\hline \multicolumn{5}{|c|}{ OKULUMDA; } \\
\hline 1 & $\begin{array}{l}\text {...belirsizlik durumlarına uyum sağlamak için değişim } \\
\text { yaşanır. }\end{array}$ & .151 & .381 & .053 \\
\hline 2 & $\begin{array}{l}\text {...̈̈ğretmen ve yöneticilerin görev dağılımı açık-net } \\
\text { bir şekilde yapılır. }\end{array}$ & .163 & .561 & .087 \\
\hline 3 & $\begin{array}{l}\text {...performans değerlendirme } \\
\text { öğretmenlerle paylaş1lır. }\end{array}$ & .042 & .583 & .006 \\
\hline 4 & $\begin{array}{l}\text {...öğretmenler, belirsizlik durumlarına çözüm önerileri } \\
\text { getirmeleri için teşvik edilir. }\end{array}$ & .075 & .606 & .064 \\
\hline 5 & $\begin{array}{l}\text {...yaşanan belirsizlik, örgüt içindeki iletişimin } \\
\text { bozulmasına neden olur. }\end{array}$ & .543 & .029 & .294 \\
\hline 6 & $\begin{array}{l}\text {...çevresel faktörler, karar verme sürecini (olumsuz } \\
\text { yönde) etkiler. }\end{array}$ & .553 & .052 & .267 \\
\hline 7 & $\begin{array}{l}\text {...belirsizlik yaşanması, okul yöneticilerinin harekete } \\
\text { geçmesini engeller. }\end{array}$ & .756 & .075 & .360 \\
\hline 8 & $\begin{array}{l}\text {...yaşanan belirsizlik, okul yöneticilerinin karar alma } \\
\text { sürecini (olumsuz yönde) etkiler. }\end{array}$ & .808 & .041 & .352 \\
\hline 9 & $\begin{array}{l}\text {...belirsizlik yaşanması durumunda, okul yönetiminin } \\
\text { tüm alanlardaki etkililiği azalır. }\end{array}$ & .630 & .086 & .306 \\
\hline 10 & $\begin{array}{l}\text {...oluşan belirsizlik ortamında alınan kararlar, tekrar } \\
\text { gözden geçirilir. }\end{array}$ & .245 & .476 & .083 \\
\hline 11 & $\begin{array}{l}\text {...oluşan belirsizlik durumlarını gidermek adına çaba } \\
\text { gösteririm. }\end{array}$ & .087 & .471 & .038 \\
\hline 12 & $\begin{array}{l}\text {...yaşanan her belirsizlik durumu karşısında, } \\
\text { kaygılanırım. }\end{array}$ & .080 & .011 & .875 \\
\hline 13 & $\begin{array}{l}\text {...yaşanan her belirsizlik durumu karşısında, stres } \\
\text { yaşarım. }\end{array}$ & .071 & .015 & .944 \\
\hline 14 & $\begin{array}{l}\text {...yaşanan her belirsizlik durumu karşısında, } \\
\text { korkarım. }\end{array}$ & .009 & .002 & .851 \\
\hline 15 & $\begin{array}{l}\text {...yaşanan her belirsizlik durumu karşısında, } \\
\text { kararsızlık yaşarım. }\end{array}$ & .006 & .069 & .805 \\
\hline 16 & $\begin{array}{l}\text {...karşıllaştığım belirsizlik durumları bende şok etkisi } \\
\text { yaratır. }\end{array}$ & .031 & .046 & .689 \\
\hline 17 & $\begin{array}{l}\text {...belirsizlik yaşanması iş motivasyonumu (olumsuz } \\
\text { yönde) etkiler. }\end{array}$ & .337 & .090 & .528 \\
\hline
\end{tabular}




\begin{tabular}{|c|c|c|c|c|}
\hline \multicolumn{5}{|c|}{ OKUL YÖNETİCILERIMMIZ; } \\
\hline 18 & $\begin{array}{l}\text {...örgütsel belirsizlik öngörü } \\
\text { ilișkisi içerisinde yapabilmede ye }\end{array}$ & .009 & .747 & .018 \\
\hline 19 & $\begin{array}{l}\text {..okulun sadece bugününü değil; aynı zamanda } \\
\text { yarınlarını da yönettiklerinin farkındadır. }\end{array}$ & .044 & .868 & .052 \\
\hline 20 & $\begin{array}{l}\text { n belirsizliğin yönetim sürecinde, } \\
\text { c1 olur. }\end{array}$ & .070 & .813 & .063 \\
\hline 21 & yollarını aramada & .050 & .817 & .036 \\
\hline 2 & $\begin{array}{l}\text {...belirsizlik durumlarında, yeni fikirler oluşm } \\
\text { imkan sağlar. }\end{array}$ & .006 & .817 & .036 \\
\hline 3 & ade, en uygun & .006 & .833 & .033 \\
\hline 4 & $\begin{array}{l}\text { i giderme sürecinde öğretmenlere } \\
\text { ağlar. }\end{array}$ & .017 & .823 & .020 \\
\hline 25 & $\begin{array}{l}\text {...belirlenmiş hedefleri gerçekleştiren eylemlerde } \\
\text { bulunur. }\end{array}$ & .010 & .833 & .008 \\
\hline 6 & $\begin{array}{l}\text {..örgütsel belirs } \\
\text { liderlik davranışla }\end{array}$ & .016 & .809 & .048 \\
\hline \multicolumn{5}{|c|}{ BENCE; } \\
\hline 27 & $\begin{array}{l}\text {...ok } \\
\text { yeter }\end{array}$ &. & .630 & .02 \\
\hline 28 & $\begin{array}{l}\text { Izun geleceği ile ilgili } \\
\text { r șekilde biliyor. }\end{array}$ & .3 & .533 & .008 \\
\hline 29 & $\begin{array}{l}\ldots \text { ok } \\
\text { kurm }\end{array}$ & 9 & .607 & .01 \\
\hline 30 & ...ça & 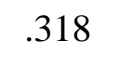 & (59) & .002 \\
\hline 32 & $\begin{array}{l}\ldots \ddot{0} \\
\text { hare }\end{array}$ & .460 & .573 & .08 \\
\hline 33 & imlarında & .502 & .506 & .018 \\
\hline 34 & syorum. & .435 & .383 & .112 \\
\hline & Özdeğer & 12.337 & 4.133 & 2.686 \\
\hline \multicolumn{5}{|c|}{$\begin{array}{l}\text { Not: Uç faktör bir arada toplam varyansın \%58.05'ini açıllamaktadır. OBD } \\
\text { Örgütsel Olumsuzlukları Cronbach's } \alpha \text { değeri .837, ÖBD Bireysel } \\
\text { Olumsuzlukların Cronbach's } \alpha \text { değeri ise } .877 \text { ve ÖBD Yönetsel Uygulamaların } \\
\text { Cronbach's } \alpha \text { değeri } .926 \text { olarak hesaplanmıştır. ÖBD Örgütsel Olumsuzluklar } \\
\text { toplam varyansın \%12'sini ve ÖBD Bireysel Olumsuzluklar toplam varyansın } \\
\% 8 \text { 'ini ve ÖBD Yönetsel Uygulamalar ise, toplam varyansın \%37'sini } \\
\text { açıklamaktadır. }\end{array}$} \\
\hline
\end{tabular}


Tablo 6 incelendiğinde ÖBD Yönetsel Uygulamalar boyutu ile yüksek ilişkide bulunan 1. madde, ikinci uygulamada yapılan AFA sonuçlarına göre her hangi bir faktör ile ilişkili bulunamamıştır. Bu nedenle ve ölçülmek istenen yapıyı ölçmede zayıf olduğu için ölçekten çıkarılmıştır. Aynı şekilde birinci uygulamada ÖBD Yönetsel Uygulamalar boyutuna yüklenen 34. madde, ikinci uygulamada yapılan AFA sonuçlarına göre ÖBD Örgütsel Olumsuzluklar boyutuna yüklenmiştir. Maddenin boyut değiştirmesi istenmeyen bir durum olduğundan 34. Madde; binişik madde özelliği gösteren 17, 29, 32 ve 33'üncü maddeler; 10. ve 11. maddeler yapılan birinci uygulamaya kıyasla ikinci uygulamada da aynı faktöre yüklenmesine rağmen faktör yüklerinin çok düştügü ve aradaki ilişkiyi zayıf olarak ortaya çıkardığı, ayrıca model uyumsuzluğunun kaynağı olduğu için ölçekten çıkartılmıştır.

Araştırmanın ikinci uygulaması sonucunda elde edilen verilere göre yapılan doğrulayıc faktör analizlerinin uyum istatistikleri özeti Tablo 7'de sunulmuştur.

Tablo 7. İkinci Uygulamaya Ait Doğrulayıcı Faktör Analizi Uyum İstatistikleri Özeti

\begin{tabular}{lccccccc} 
MODEL & $\mathrm{X}^{2}$ & $\mathrm{sd}$ & $\mathrm{p}$ & CFI & TLI & RMSEA & G.A. \\
\hline DFA 1 & 1.998 .218 & 347 & .000 & .941 & .936 & .074 & $(.071, .077)$ \\
DFA 2 & 1.582 .524 & 321 & .000 & .955 & .951 & .067 & $(.064, .070$ \\
DFA 3 & 1.276 .461 & 272 & .000 & .963 & .959 & .065 & $(.062, .069)$ \\
DFA 4 & 1.177 .278 & 271 & .000 & .967 & .963 & .062 & $(.058, .066)$ \\
\hline
\end{tabular}

Not: sd: Serbestlik Derecesi, CFI: Karşılaştırmalı Uyum İndeksi, TLI: Tucker ve Levis'in Uyum İndeksi, RMSEA: Yaklaşık Ortalama Karekök Hatası, G. A.: RMSEA için \%90 Güven aralığı, K. A. V.: Kümülatif Açıklanan Varyans.

Tablo 7 incelendiğinde, model uyum indekslerinin her bir yeni modelde daha da geliştiği görülmektedir. DFA modellerinin uyum istatistik değerleri incelendiğinde; birinci modelin uyum istatistik değerleri kabul edilebilir uyum; iki, üç ve dördüncü modellerin uyum istatistik değerleri iyi bir uyuma işaret etmektedir. Ancak son model olarak analiz edilen dördüncü modelde 12 ve 13. maddelerin hata varyansları arasındaki korelasyon serbestçe hesaplanmıştır. Ardından aynı veriler üzerinde yeni bir DFA yapılmıştır. Bütün kriterler göz önünde bulundurulduğunda, iyi uyum koşulunun en iyi şekilde sağlandığ 1 modelin dördüncü model olduğu görülmektedir.

Araştırmanın ikinci uygulaması sonucunda elde edilen verilere göre yapılan Doğrulayıcı Faktör Analizi sonuçları Tablo 8'de sunulmuştur. 
Tablo 8. İkinci Uygulamaya Ait Doğrulayıcı Faktör Analizi Sonuçları

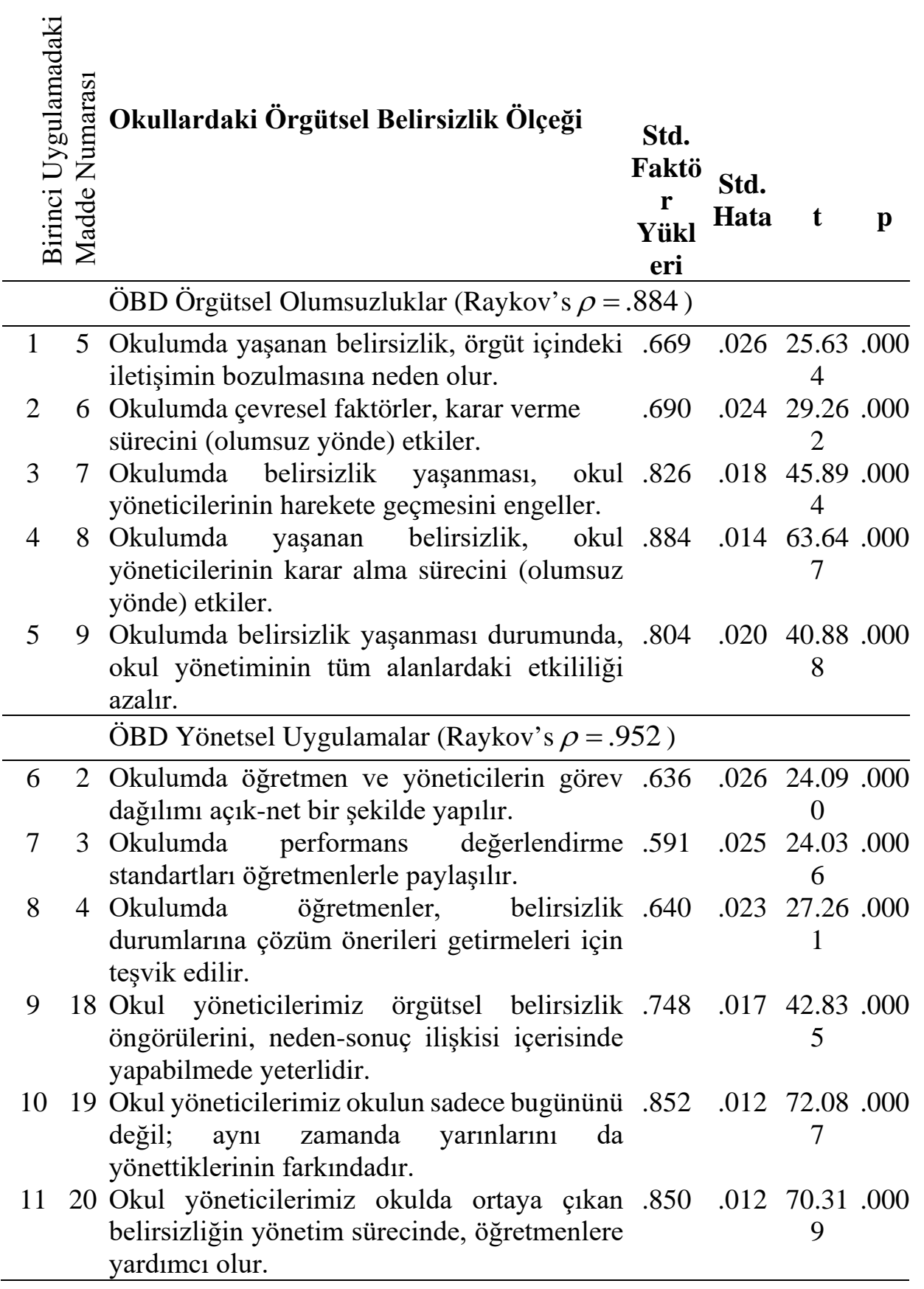




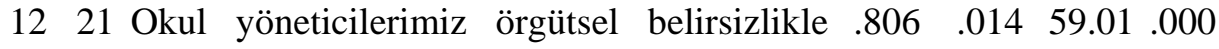
başa çıkma yollarını aramada öğretmenlerden $\quad 6$ destek alır.

1322 Okul yöneticilerimiz belirsizlik durumlarında, .811 $\quad .014 \quad 58.31 .000$ yeni fikirler oluşmasına imkan sağlar.

1423 Okul yöneticilerimiz okuldaki belirsizliğin $\quad 842 \quad 01271.66 .000$ giderilmesinde, en uygun yöntemleri seçmede yeterlidir.

1524 Okul yöneticilerimiz örgütsel belirsizliği $\quad 827 \quad 013 \quad 64.29 .000$ giderme sürecinde öğretmenlere anında $\quad 8$ geribildirim sağlar.

1625 Okul yöneticilerimiz belirlenmiş hedefleri $.843 \quad 012 \quad 69.15 .000$ gerçekleştiren eylemlerde bulunur.

1726 Okul yöneticilerimiz örgütsel belirsizlik $.836 \quad .013 \quad 66.86 .000$ $\begin{array}{llll}\text { durumunda ihtiyaç duyulan liderlik } & 7\end{array}$ davranışlarını göstermede yeterlidir.

1827 Bence okulum, ortaya çıkan beklenmedik $.737 \quad 018 \quad 41.45 .000$ durumlara, yeterince uyum sağlayabilir. $\quad 4$

1928 Bence öğretmenler okulumuzun geleceği ile $\quad \begin{array}{llll}614 & .024 & 25.70 & .000\end{array}$ ilgili beklentileri, açık ve net bir şekilde 1 biliyor.

2030 Bence çalıştığım okulda örgüt kültürü $\quad 650 \quad 022 \quad 29.01 \quad 000$ hissedilir. ÖBD Bireysel Olumsuzluklar (Raykov's $\rho=.853$ )

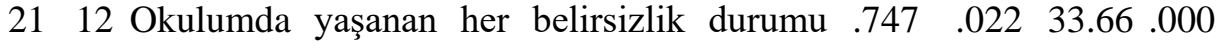
karşısında, kaygılanırım.

2213 Okulumda yaşanan her belirsizlik durumu $.834 \quad .017 \quad 50.15 .000$ karşısında, stres yaşarım.

2314 Okulumda yaşanan her belirsizlik durumu $.893 \quad .015 \quad 61.48 .000$ karşısında, korkarım.

2415 Okulumda yaşanan her belirsizlik durumu $.878 \quad .015 \quad 58.63 .000$ karşısında, kararsızlık yaşarım.

8

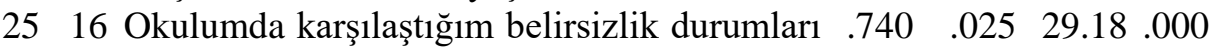
bende şok etkisi yaratır.

1

Not: 12. ve 13. maddelerin hata varyansları arasındaki korelasyon 0'da sabit tutulmak yerine serbestçe hesaplanarak .633 bulunmuştur. Ayrıca ÖBD Yönetsel Uygulamaların faktör puanları ile ÖBD Örgütsel Olumsuzlukların faktör puanları arasındaki korelasyon $r=-.403$, ÖBD Bireysel Olumsuzlukların faktör puanları ile ÖBD Örgütsel Olumsuzlukların faktör puanları arasındaki korelasyon $r=$ .354, ÖBD Bireysel Olumsuzlukların faktör puanları ile ÖBD Yönetsel 
Uygulamaların faktör puanları arasındaki korelasyon ise $r=-.259$ olarak kestirilmiştir.

Tablo 8 incelendiğinde, ÖBD Bireysel Olumsuzluklar boyutunda yer alan 14. madde (Std. faktör yükü .893) en yüksek faktör yüküne sahiptir. Boyutların faktör puanları arasındaki korelasyon değerleri incelendiğinde; en yüksek korelasyonun ÖBD Bireysel Olumsuzluklar ve ÖBD Örgütsel Olumsuzluklar boyutları arasında $(r=.354)$, en düşük korelasyonun ise ÖBD Örgütsel Olumsuzluklar ve ÖBD Yönetsel Uygulamalar boyutları arasında $(r=-.403)$ olduğu görülmektedir. Örgütsel belirsizliğin en yüksek güvenirliğe sahip olan boyutu ÖBD Yönetsel Uygulamalardır (Raykov's $\rho=.952$ ). Onu ÖBD Örgütsel Olumsuzluklar boyutu (Raykov’s $\rho=.884$ ) takip ederken, en düşük güvenirliğe ise ÖBD Bireysel Olumsuzluklar boyutu (Raykov's $\rho=.853$ ) sahiptir. Tablo 8 'in altında belirtilen nedenden ötürü 12 . ve 13 . maddelerin hata varyansları arasındaki korelasyon serbestçe hesaplanarak alt bilgide verilmiştir. Örgütsel belirsizliğin boyutlarının faktör puanları arasındaki korelasyon değerleri de ayrı ayrı hesaplanarak yine alt bilgide verilmiştir. Her bir madde ölçeğin son halinde yer almak üzere tablonun solunda yer alan sütunda yeniden numaralandırılmıştır.

Araştırma sorularının cevaplandırılması için oluşturulacak olan iki basamaklı yapısal regresyon modelinde söz konusu model ölçme modeli olarak yer almaktadır. Kullanılan ölçme modeli Şekil 1'de sunulmuştur.

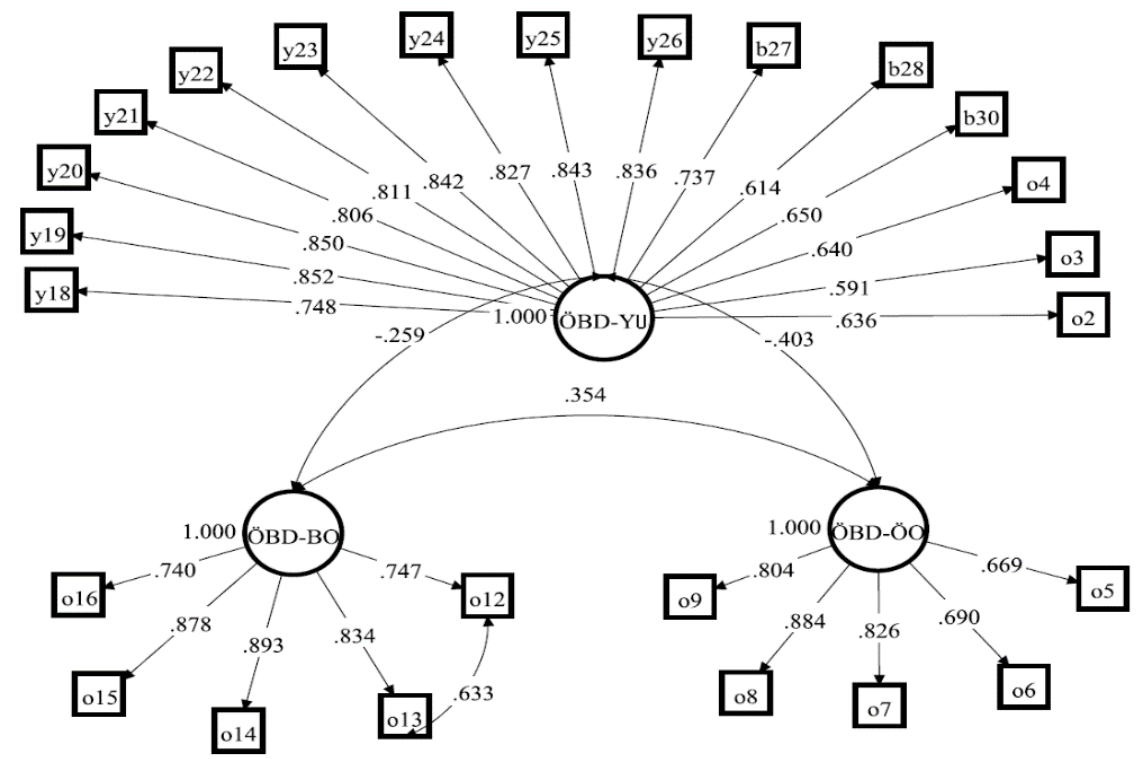

Şekil 1.Yapısal Regresyon Ölçme Modeli 
Tüm bu bulgular sonucunda geliştirilen ölçeğe ilişkin maddeler ve boyutlar Tablo 9'da sunulmuştur.

Tablo 9. Ölçekteki Maddelerin Boyutlara Göre Dağılımı

\begin{tabular}{ll}
\hline Boyut İsimleri & Maddeler \\
\hline ÖBD Örgütsel & $1,2,3,4$ ve 5 \\
Olumsuzluklar & $6,7,8,9,10,11,12,13,14,15,16,17$, \\
ÖBD Yönetsel & 18,19 ve 20 \\
Uygulamalar & $21,22,23,24$ ve 25 \\
ÖBD Bireysel & \\
Olumsuzluklar & \\
\hline
\end{tabular}

\section{TARTIŞMA VE SONUÇLAR}

Okullardaki Örgütsel Belirsizlik Düzeyini Belirleme Ölçeğini (OÖBÖ) geliştirmek amacıyla ilgili literatür taraması yapılarak 47 maddelik bir soru havuzu oluşturulmuştur. Oluşturulan bu soru havuzu uzman görüşü de alınarak 39 maddeye indirilerek farklı branşlardan 8 öğretmenle bilişsel görüşme yapılarak birinci uygulama için ölçek hazır hale getirilmiştir. Birinci uygulama Siirt ili Kurtalan ilçesinde 564 katılımcıya uygulanmıştır. Birinci uygulama sonucunda elde edilen verilere dayalı ölçeğin yapı geçerliliği için Açımlayıcı Faktör Analizi (AFA) ve Doğrulayıcı Faktör Analizi (DFA) uygulanmış olup, FIT değerlerine göre modellenerek ölçeğin en uygun faktör değerleri belirlenmiştir. Birinci uygulama sonucunda 39 maddelik ölçek 34 maddeye indirilerek Siirt Merkezinde 871 katılımcıya ikinci uygulaması yapılmıştır. İkinci uygulama sonrasında elde edilen verilere AFA, DFA ve FIT analiz prosedürleri uygulanmıştır. Yapılan güvenirlik analizleri donucunda 25 maddelik ve 3 boyutlu bir yapıya ulaşılmıştır. Bu boyutlar; ÖBD Örgütsel Olumsuzluklar (5 madde), ÖBD Yönetsel Uygulamalar (15 madde) ve ÖBD Bireysel Olumsuzluklar (5 madde) olarak isimlendirilmiştir. Ölçeğin toplam açıkladığı varyans \%58,05 olup, bu değer bize ölçeğin oldukça yüksek bir açımlayıcılığa sahip olduğunu göstermektedir. Tüm bu istatistiki bulgular, yapılan analizler ve modellemeler bize geliştirilen OÖBÖ'nin istenilen yapıyı geçerli ve güvenilir bir şekilde ölçebildiğini göstermektedir. Çünkü örgütlerde belirsizliğin giderilmesi adına örgütsel örtük bilginin elde edilip belirsizliğin giderilmesinde kullanılması oldukça önemlidir (Polat ve Arabacı, 2015). Çünkü yapılan araştırma sonuçları, çalışanların işten ayrılma niyetlerini, büyük ölçüde, algıladıkları belirsizliğin etkili olduğu göstermektedir (Karakuş ve Yardım, 2014). Tüm bu parametreler göz önünde bulunduğunda eğitim-öğretim sisteminin beklenen kısa, orta ve uzun vadedeki amaçlarının etkili bir şekilde elde edilmesi için, etkili okullara ihtiyacı 
vardır. Etkili okul örgütlerinin oluşması için de örgütsel belirsizliğin belirlenmesi ve giderilmesi gerekli olduğu görülmektedir. Geliştirilin Okullardaki Örgütsel Belirsizlik Düzeyini Belirleme Ölçeği (OÖBÖ) bu bağlamda etkili okul örgütleri oluşturmada amaca ulaşmada önemli bir katkı sağlayacaktır.

\section{KAYNAKÇA}

Armutlulu, İsmail Hakkı (2014). Belirsizlik ve Fazi Aritmetiği Sosyal Bilimlerin Dili. Alfa Yayınları, İstanbul.

Aydın, Mustafa (2014). Eğitim Yönetimi. Gazi Kitabevi, Ankara.

Bakioğlu, Ayşe ve Demiral, Seyhan (2013). "Okul Yöneticilerinin Belirsizlik Durumlarını Algılama Ve Karar Verme Tarzları", Eğitim Bilimleri Dergisi, 38, ss.9-35.

Barnard, Chester (1938). The Functions Of The Executive. Cambridge, Harvard University Press, Massachusetts.

Bentler, Peter (1990), "Comparative Fit Indexes in Structural Models", Psychological Bulletin, 107 (2), ss.238-46.

Bentler, Peter ve Chou, Chih-Ping (1987). "Practical Issues in Structural Modeling.” Sociological Methods and Research, 16 (1), ss.78-117.

Browne, Micheal and Cudeck, Robert (1993). “Alternative Ways of Assesing Model Fit”. In K. A. Bollen \& J. S. Long (Eds.), Testing structural euation models (pp. 136-162). Sage Publications, Newbury Park, CA.

Clampitt, Phillip. G.; DeKoch, Robert J. and Cashman, Thomas (2000). “A Strategy For Communicating About Uncertainty” Academy of Management Perspectives, 14 (4), ss.41-57.

Cronbach, Lee J. (1951). "Coefficient Alpha And The Internal Structure Of Tests”, Psychometrika, 16, ss.297-334.

Dağtaş, Aysun (2018). Exploring Foreign Language Learners’ Uncertainty Experiences and Uncertainty Management. Doktora Tezi. Çağ Üniversitesi Sosyal Bilimler Enstitüsü, Mersin

Eren, Erol (2015). Örgütsel Davranış ve Yönetim Psikolojisi, (On beşinci Bask1). Beta Basım, İstanbul. 
Eren, Zeynep (2020). “Complexity Leadership”, In Ozgür Demirtas \& Mustafa Karaca (Eds.), A handbook of leadership styles (pp. 296-428). Cambridge Scholars Publishing, Newcastle, UK.

Gleick, James (1996). Kaos Yeni Bir Bilim Teorisi. (Çev. Fikret Üçcan). TÜBİTAK Popüler Bilim Kitapları, Ankara.

Hofstede, Geert (2011). "Dimensionalizing Cultures: The Hofstede Model in Context.” Online Readings in Psychologyand Culture, 2(1), pp.1-26. .http://dx.doi.org/10.9707/2307-0919.1014

Karakuş, Şenay ve Yardım, Mecbure (2014). “Algılanan Örgütsel Değişim, Belirsizlik, İş Doyumu Ve İşten Ayrılma Niyeti Arasındaki İlişkiler”, İş ve İnsan Dergisi, 1(1), ss.21-31.

Kline, Rex B. (2015). "Yapısal Eşitlik Modellemesinin İlkeleri ve Uygulaması" (Çeviri Editörü. Sedat Şen). Nobel Akademik Yayıncılık, Ankara.

Muthén, Linda K. and Muthén, Bengt O. (1998-2012). Mplus Statistical Analysis With Latent Veriables User's Guide. (Version 7.3) [computer software]. Author, Los Angeles.

Moles, Abraham (2018). Belirsizin Bilimleri: İnsan Bilimleri İçin Yeni Bir Epistemoloji. (Çev. Nuri Bilgin). Yapı Kredi Yayınları, İstanbul.

Polat, Murat (2016). Yükseköğretimde Örgütsel Belirsizlik Sosyal Ağları Benimseme ve Açık Liderlik. Nobel Akademik Yayıncılık, Ankara.

Polat, Murat ve Arabac1, İmam Bakır (2015). "Enformasyon Kuramı Bağlamında Sosyal Ağlar, Örgütsel Belirsizlik ve Eğitim: Kavramsal Bir Analiz", Journal of International Social Research, 8(37), pp.797809.

Steiger, James H. (1990). "Structural Model Evaluation And Modification: An İnterval Estimation Approach”, Multivariate Behavioral Research, 25 (2), 173-180.

Sönmez, Veysel ve Alacapınar, Füsun G. (2014). Örneklendirilmiş Bilimsel Araştırma Yöntemleri. Anı Yayıncılık, Ankara.

Tinaztepe, Cihan (2010). The Effect of Desire for Change on The Relationship Between Perceived Uncertainty and Job Related Affective WellBeing. Yayımlanmamış Yüksek Lisans Tezi. Marmara Üniversitesi Sosyal Bilimler Enstitüsü, İstanbul. 
Toytok, Esef Hakan ve Doğan, Emine (2019). “Okullarda İnformel İletişimi Kullanma Ölçeği'nin Geliştirilmesi Çalışması”, Electronic Journal of Social Sciences, 18 (70), pp.852-865.

Tucker, Ledyard R. and Lewis, Charles (1973). "A Reliability Coefficient For Maximum Likelihood Factor Analysis”, Psychometrika, 38 (1), ss.110.

Uz, İrem (2015). "Nedensel Belirsizlik Ölçeğinin Türkçeye Uyarlanması”, Anadolu Psikiyatri Dergisi, 16, ss.19-22.

Willis, Gordan B. (1999). Cognitive Interviewing: A “How To" Guide.Research Triangle Institute, Research Triangle Park. NC.

Yazıcıoğlu, Yahşi ve Erdoğan, Samiye (2004), SPSS Uygulamalı Bilimsel Araştırma Yöntemleri, Detay Yayıncılık, Ankara. 